\title{
Biomarkers and bioindicators of the environmental condition using a fish species (Pimelodus maculatus Lacepède, 1803) in a tropical reservoir in Southeastern Brazil
}

\author{
F. G. Araújo * , C. N. Morado ${ }^{a}$, T. T. E. Parente , F. J. R Paumgartten $^{b}$ and I. D. Gomes ${ }^{a}$ \\ ${ }^{a}$ Laboratório de Ecologia de Peixes, Universidade Federal Rural do Rio de Janeiro - UFRRJ, BR 465, Km 7, \\ CEP 23890-000, Seropédica, RJ, Brazil \\ bLaboratório de Toxicologia Ambiental, Escola Nacional de Saúde Pública, Fundação Oswaldo Cruz, Av. Brasil, 4325, \\ CEP 21045-900, Rio de Janeiro, RJ, Brazil \\ *e-mail: gersonufrrj@gmail.com
}

Received: July 28, 2016 - Accepted: December 19, 2016 - Distributed: 31 May, 2018

(With 2 figures)

\begin{abstract}
The Funil Reservoir receives a large amount of xenobiotics from the Paraíba do Sul River (PSR) from large number of industries and municipalities in the watershed. This study aimed to assess environmental quality along the longitudinal profile of the Paraíba do Sul River-Funil Reservoir system, by using biomarkers and bioindicators in a selected fish species. The raised hypothesis is that Funil Reservoir acts as a filter for the xenobiotics of the PSR waters, improving river water quality downstream the dam. Two biomarkers, the ethoxyresorufin- $O$-deethylase activity (EROD), measured as fluorimetricly in $\mathrm{S} 9$ hepatic fraction, and the micronuclei frequency $(\mathrm{MN})$, observed in erythrocytes of the cytoplasm, and three bioindicators, the hepatosomatic index (HSI), gonadosomatic index (GSI) and condition factor (CF) were used in Pimelodus maculatus, a fish species widely distributed in the system. Four zones were searched through a longitudinal gradient: 1 , river upstream from the reservoir; 2, upper reservoir; 3 , lower reservoir; 4 , river downstream of the reservoir. EROD activity and HSI and GSI had significant differences among the zones $(P<0.05)$. The upper reservoir had the lowest EROD activity and HSI, whereas the river downstream of the reservoir had the highest EROD and lowest GSI. The river upstream from the reservoir showed the highest HSI and GSI. It is suggested that the lowest environmental condition occur at the river downstream of the reservoir, where it seems to occur more influence of xenobiotics, which could be associated with hydroelectric plant operation. The hypothesis that Funil reservoir acts as a filter decanting pollution from the Paraíba do Sul River waters was rejected. These results are novel information on this subject for a native fish species and could be useful for future comparisons with other environments.
\end{abstract}

Keywords: biomonitoring, EROD, fishes, pollutants, reservoirs.

\section{Biomarcadores e bioindicadores da condição ambiental usando uma espécie de peixe (Pimelodus maculatus Lacepède, 1803) em um reservatório tropical no Sudeste do Brasil}

\section{Resumo}

O reservatório do Funil recebe uma grande quantidade de contaminantes xenobióticos do Rio Paraíba do Sul (RPS) provenientes de grandes indústrias e municípios situados na bacia hidrográfica. O objetivo deste estudo é avaliar a qualidade ambiental ao longo de um perfil longitudinal do sistema rio Paraíba do Sul-reservatório do Funil, através de biomarcadores e bioindicadores em uma espécie de peixe selecionada. A hipótese a ser testada é de que o reservatório do Funil funciona como filtro para poluentes xenobioticos de águas do rio Paraíba do Sul, melhorando a qualidade da água à jusante da represa. Foram usados dois biomarcadores: a atividade de etoxiresorufina-O-desetilase (EROD), medida fluorimetricamente na fração S9 hepática, e a Freqüência de Micronúcleos (MN), observada no citoplasma dos eritrócitos; e também três bioindicadores: Índice hepato-somático (IHS), Índice gonado-somático (IGS) e Fator de Condição (FC) em Pimelodus maculatus, uma espécie de peixe amplamente distribuída no sistema. Quatro zonas foram amostrados ao longo do gradiente longitudinal: 1, rio a montante do reservatório; 2, parte superior do reservatório; 3, parte inferior do reservatório; 4, rio à jusante do reservatório. A atividade de EROD, o IHS e o IGS apresentaram diferenças significativas $(\mathrm{P}<0.05)$ entre as zonas. A atividade EROD e o IHS foram mais baixos na parte superior do reservatório, enquanto que no rio à jusante do reservatório, a atividade de EROD foi mais alta e o IGS foi mais baixo. O rio acima do reservatório apresentou maiores IHS e IGS. É sugerido que a pior condição ambiental ocorreu no rio 
abaixo do reservatório, o que poderia ser associado às influências das operações da usina hidroelétrica. A hipótese de que o reservatório do Funil atue como filtro decantando a poluição do rio Paraíba do Sul foi rejeitada. Estes dados são novas informações sobre este tema para uma espécie nativa e podem ser úteis para futuras comparações outros ambientes.

Palavras-chave: biomonitoramento, EROD, peixes, poluentes, reservatórios.

\section{Introduction}

The development of agricultural and industrial activities contribute to production of xenobiotics that can cause undesirable effects in aquatic systems depending on their toxicity and concentration (Hutzinger and Veerkamp, 1981; Clements, 2000; Van der Oost et al., 2003). Measurements of xenobiotic concentrations are expensive and do not supply the amount of the impact on the biological compartment (Solé et al., 2009; Schirmer et al., 2011). The recent advances in the ecotoxicology field had supplied a number of the biomarkers in organism, which can be used to estimate either exposure to chemicals or resultant effects (Handy et al., 2003; Lu et al., 2009; Ramsdorf et al., 2012). Biomarkers and bioindicators has been extensively used as proxies to determine responses at individual level to stressors, with biomarkers being more species-specific and with higher variability of responses compared to bioindicators (Schulz and MartinsJunior, 2001; Solé et al., 2010; Linde-Arias et al., 2008a, b; Barrilli et al., 2015). The integrated use of biomarkers and bioindicators is suggested as an evaluation tool, since they are effective means to determine the impact of pollution in the aquatic environment (Mc Carthy and Schugart, 1990; Reynolds et al., 2003). Moore and Simpson (1992) and Pacheco and Santos (2002) reported that the information supplied by a given biomarker individually is limited, due to great probability of incorrect interpretation. Therefore, the use of a set biomarkers and bioindicators should be used to better assess environmental condition.

Induction of the hepatic cytochrome P450-monooxygenase measured as EROD activity is a sensitive indicator of environmental alteration and usually one of the first detectable, quantifiable responses to chemical exposure in fishes (Stegeman and Lech, 1991; Stegeman, 1992; Stegeman et al., 1997; Parente et al., 2011, 2015). The most potent inducing to these isoform are the pollutants of the polychlorinated biphenyls (PCBs) group, polycyclic aromatic hydrocarbons (PAHs) and dioxins (e. g. tetrachlorodibenzo$p$-dioxin (TCDD) and Dichloro-Diphenyl-Trichloroethane (DDT)) (Jung et al., 2001). Owing to this fact, activity of CYP1A subfamily in fish liver has been extensively used as a biomarker of aquatic contamination by industrial pollutants (Pacheco and Santos, 1998; Bainy et al., 1999; Whyte et al., 2000; Parente et al., 2004).

Micronuclei are biomarkers at celular level to exposition of fish to genotoxic compounds that can cause chromosome fragmentation, chromossome lag at cell division due to the lack of centromere, damage, or a defect in cytokinesis (Al-Sabti and Metcalfe, 1995; Çavaş and Ergene Gozu-Kara, 2005a, b; Srivastava and Singh, 2015). Its determination is more simple than EROD activity, although being a sensible to pollutant occurrence (Al-Sabti and Metcalfe, 1995).

The hepatosomatic index (HSI) is a widely known as bioindicator of contaminant exposure (Goede and Barton, 1990; Sadekarpawar and Parikh, 2013). Because the liver is so important in detoxification, exposure to contaminants can lead to an increase in liver size from hypertrophy (an increase in size), hyperplasia (an increase in number) of hepatocytes (Goede and Barton, 1990; Solé et al., 2010), or both. Studies evaluating the relative liver size of fishes from contaminated sites and last disturbed sites often utilize the HSI, which expresses liver size as a percentage of total body weight (Facey et al., 1999; Sadekarpawar and Parikh, 2013).

The gonadosomatic index (GSI) is a bioindicator that supply structural information, more than functional to respect of health and gonadal maturation status. There is evidence that the majority of the species undergo reproductive cycle and, frequently, variation in the gonadal size is observed across of the cycle (De Vlaming et al., 1981; Sakamoto et al., 2003; Sadekarpawar and Parikh, 2013). Consequently, calculanting the gonadal weight as a percentage of the body weight has been used for determining the reproductive maturity, as well as responses to environmental dynamics (e.g., seasonal changes) or exogenous stress (e.g., exposition to contaminants). There is significative evidence that exposition to several environmental pollutants can result in gonad alterations like reduction of GSI, morphological changes, or both (Choudhury et al., 1993; Sakamoto et al., 2003).

The condition factor - CF (Le Cren, 1951) is a quantitative indicator of individual well being, reflecting recent food availability conditions. There is also some argument that CF can increase in polluted and rich organic matter areas due to increased feeding sources used by tolerant species that take advantage of this resources (Lohani and Santos, 1994). It is the proportion of the weight related to length, being an indirect measure of the fish energy reserves. Since this bioindicator is sensible to stress in natural environment, the condition factor can also be employed as an integrative bioindicador (Sutton et al., 2000; Barrilli et al., 2015).

The Funil reservoir was built in 1969 and has received large pollutants loads from the industrial municipalities located in the watershed, mainly from petrochemical, fertilizers and pesticides brought into the reservoir by the Paraíba do Sul River (PSR). According Klapper (2003) large reservoirs act as a decanting filter to the pollution, improving the water quality of the river downstream of the dam. Changes of the flow by forcing the energy gradient to approach near zero results in a loss of transport capacity 
and leads to sediment deposition. Coarse sediments are initially trapped and deposited at the head of the reservoir forming a delta, while smaller particles will move into a reservoir before depositing. Because there are a variety of contaminants associated with sediment particles, and because they also accumulate in reservoirs, these lentic system can trap pollutants excluding from biological cycle and improving water quality downstream the reservoir (Shotbolt et al., 2005). Reservoir trap efficiency is frequently reported as 70-90 per cent of the sediment volume delivered from the watershed (Sundborg, 1992; Toniolo and Schultz, 2005). Therefore, evaluation the environmental quality along the longitudinal profile of the Paraíba do Sul River - Funil reservoir system, by using biomarkers and bioindicators in one Siluriform fish species that is widely distributed across the system. Siluriformes fishes, according to Whyte et al. (2000) are good candidate species for biomonitoring because they have a wide range between basal and induced EROD activity. The hypothesis of the reservoir to act as a filter for polluted Paraíba do Sul River waters was tested. We ask the following questions: 1. Do exist differences in biomarkers and bioindicators values between the sampled zones (river upstream from the reservoir; upper reservoir; lower reservoir; and river downstream of the reservoir) that could indicate a environmental quality gradient? 2. Do the biomarkers/bioindicators and the fish species used are efficient for indication of eventual environmental alterations? 3. Does the Funil reservoir improve the water quality of the Paraiba do Sul River downstream the dam?

\section{Material and Methods}

\subsection{Study area}

The Funil reservoir (Figure 1) is located in Rio de Janeiro State $\left(22^{\circ} 30^{\prime}-22^{\circ} 37^{\prime} \mathrm{S} ; 44^{\circ} 33^{\prime}-44^{\circ} 44^{\prime} \mathrm{W}, 440 \mathrm{~m}\right.$ above sea level), and blocks the Paraíba do Sul River in its middle reaches. The reservoir has a $40 \mathrm{~km}^{2}$ area, mean depth of $22 \mathrm{~m}$, and retention time of 10 to 50 days. The average monthly temperature ranges from $22{ }^{\circ} \mathrm{C}$ to $27{ }^{\circ} \mathrm{C}$, river inflow is $200-500 \mathrm{~m}^{3} \times \mathrm{sec}^{-1}$, and accumulated rainfall in summer is 1500 and in winter is $900 \mathrm{~mm}$. The main longitudinal axis of the reservoir follows the river channel, corresponding to the enlargement of the Paraíba do Sul river bed. The vegetation around the reservoir is very poor, a result of previous agricultural use for coffee plantation and pasture. The water level oscillation contributes to shoreline erosion increasing sedimentation in the reservoir. Reforestation programmes are being implemented by the power generation company responsible for the reservoir.

The PSR receives in the reaches upstream from the reservoir large loads of domestic and industrial pollutants from a number of municipalities, which has caused dramatic eutrophication in Funil reservoir in recent decades, resulting in frequent and intense cyanobacterial blooms (Klapper, 1998; Branco et al., 2002; Rocha et al., 2002; Costa et al., 2006).

\subsection{Data collection}

The species used for this study is a Siluriformes fish (Pimelodus maculatus Lacépède, 1803) that is abundant and widely distributed in the whole river-reservoir system.

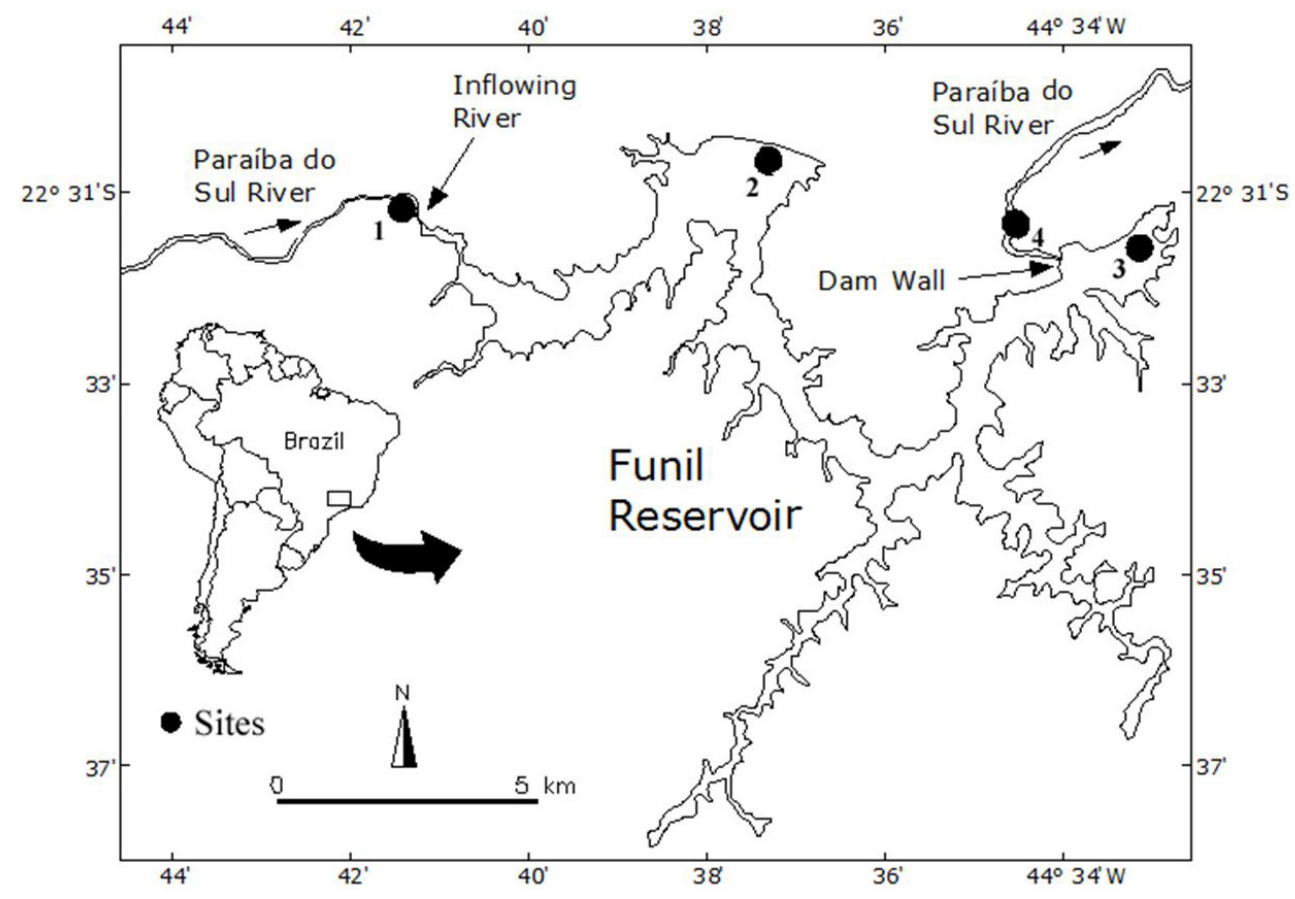

Figure 1. Map of the Funil reservoir with indication of the four studied zones. 1, river upstream from the reservoir; 2, upper reservoir; 3, lower reservoir; 4, river downstream of the reservoir. 
References for feeding in Pimelodus maculatus from different localities, reported a wide and diverse diet. Arciffa et al. (1988) regarded it as species as omnivore. Lolis and Andrian (1996) considered this species (adult specimens) omnivore with tendency to piscivory.

Fishes were collected in November 2007 in the four zones: zone 1, river upstream from the reservoir; zone 2, upper reservoir; zone 3, lower reservoir; and zone 4, river downstream of the reservoir. Only adult fishes were used to eliminate the interference of growth and physiological ontogenetic changes. A total of 10 individuals were examined from each zone totaling 40 individuals that were used in each analysis (Erod, Micronuclei frequency, $\mathrm{CF}$, HSI and GSI). Macroscopic maturation stages were determined. Gonads were fixed in buffered formalin and weighted. Fish total length averaged $25.93 \mathrm{~cm}$, ranging from 17 to $34.5 \mathrm{~cm}$.

\subsection{Chemicals}

Substrates (ethoxyresorufin), the reaction product (resorufin), ß-NADP, glicose-6-phosfate, glucose-6phosphatedehydrogenase, bovine serum albumin and the Bradford reagent were all purchased from Sigma Chemical Company, St Louis MO, USA. TRIS, $\mathrm{MgCl}_{2}$ and other salts were of analytical grade and supplied by Merck SA Industrias Quimicas, Rio de Janeiro, Brazil.

\subsection{EROD activity assay}

All fish were measured, weighed and killed with a cephalic blow. Livers were then rapidly excised, weighed and frozen in liquid nitrogen until further use. Three frozen livers from fish collected at the same sampling site were thawed on ice and homogenized in a cold buffer solution (50 mM Tris, 1 mM EDTA, 250 mM sucrose, 20\% glycerol, $\mathrm{pH}$ 7.4) by using a motor-driven glass Potter-Elvejhem homogenizer equipped with a Teflon pestle. Hepatic homogenates were subsequently centrifuged at $9,000 \mathrm{~g}$ for $30 \mathrm{~min}$ at $4{ }^{\circ} \mathrm{C}$. Aliquots $(1 \mathrm{ml})$ of the supernatant (liver S9 fraction) were transferred to cryotubes and stored in liquid nitrogen until they were assayed for monooxygenase activity. Protein concentrations in the S9 fractions were measured by a colorimetric method (absorbance at $595 \mathrm{~nm}$ ) using Coomassie brilliant Blue $\mathrm{G}$ dye and bovine serum albumin as the standard. Details of the method used for protein quantification were reported by Bradford (1976).

Ethoxyresorufin-O-deethylase (EROD) activity in the hepatic S9 fractions were assayed essentially as described by Burke et al. (1985) except for the use of a NADPH regenerating system. Reactions were carried out in quartz cuvettes at $37^{\circ} \mathrm{C}$ and were started by addition of the regenerating system which consisted of $0.25 \mathrm{mM}$ b-NADP, $2.5 \mathrm{mM} \mathrm{MgCl2}, 5 \mathrm{mM}$ glycose-6-phosphate, and 0.5 units of glucose-6-phosphate-dehydrogenase per $\mathrm{ml}$ of incubation mixture. The rate of resorufin formation was measured fluorimetrically. The spectrofluorimeter (Shimadzu RF-5000) settings were as follows: excitation at $550 \mathrm{~nm}$, emission at $582 \mathrm{~nm}$ and a $5 \mathrm{~nm}$ band slit width.

\subsection{Micronuclei frequency}

A drop from peripheral blood was directly smeared on slides and air-dried. Smears were subsequently fixed in methanol for $10 \mathrm{~min}$, and were stained with $10 \%$ Giemsa solution for $6 \mathrm{~min}$. The frequency of $\mathrm{MN}$ evaluated (per 1,000 cells) by scoring at a $1,000 \times$ magnifications using Olympus BX 45 microscope. Only erythrocytes with intact cellular and nuclear membrane were examined. Round or ovoid-shaped non-refractory particles with color and structure similar to chromatin, with a diameter $1 / 3-1 / 20$ of the main nucleus and clearly detached from it were interpreted as $\mathrm{MN}$.

\subsection{Bioindicators}

Three bioindicators were used: hepato-somatic index (HSI), gonadosomatic index (GSI) and condition factor (CF), according to the following equations. The HSI = (liver weight $\times$ total $\left.^{\text {weight }}{ }^{-1}\right) \times 100$ GSI $=($ gonad weight $\times$ total weight $\left.^{-1}\right) \times 100 \mathrm{CF}=\left(\right.$ total weight $\times$ total lenght $\left.^{-3}\right) \times 100$.

\subsection{Statistical analysis}

One way analysis of variances (ANOVA) and Tukey HSD multiple comparison test were carried out to compare means values of each biomarker and bioindicator among the studied zones at the level of significance $\alpha=5 \%(\mathrm{P}<0.05)$.

\section{Results}

The means of EROD activity detected in P. maculatus was significantly lower $(P<0.05)$ in fishes caught in zone 2 (upper reservoir) compared with those in zone 4 (river downstream of the reservoir) that had the highest values (Table 1; Figure 2). Frequency of micronuclei did not change significantly among the four zones, although a slight trend for the highest values was observed for zone 1 (river upstream the reservoir) and lowest values in zone 3 (lower reservoir).

Table 1. F-values and P-significance from ANOVA for differences in biomarkers and bioindicators among the zones.

\begin{tabular}{ccll}
\hline $\begin{array}{c}\text { Biomarker/ } \\
\text { Bioindicator }\end{array}$ & F & \multicolumn{1}{c}{$P$} & \multicolumn{1}{c}{ Tukey differences } \\
\hline EROD & 4.97 & $0.0030 * *$ & 4 (river downstream reservoir) $>2$ (upper reservoir) \\
MN & 2.06 & 0.1287 & ns \\
HSI & 3.20 & $0.0368 *$ & 1 (river upstream reservoir) $>2$ (upper reservoir) \\
GSI & 4.65 & $0.0079 * *$ & 1 (river upstream reservoir) $>4$ (river downstream reservoir) \\
CF & 2.85 & 0.0511 & ns \\
\hline
\end{tabular}

$* \mathrm{P}<0.05$ - Significant; ns, non-significant; $* * \mathrm{P}<0.001$, Highly significant. 


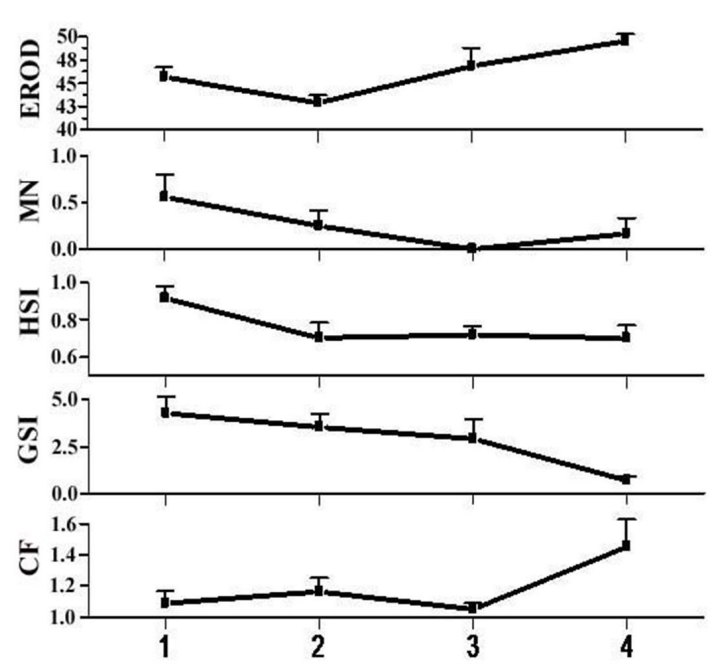

Figure 2. Means and standard errors for biomarkes (EROD, Ethoxyresorufin- $O$-deethylase activity $(\mathrm{pmol} / \mathrm{min} / \mathrm{mp}$ of protein), and $\mathrm{MN}$, micronuclei frequency per 1000 cells, and bioindicators (HSI, hepatosomatic index, GSI, gonadosomatic index and $\mathrm{CF}$, condition factor) in the four studied zones.

The bioindicator HSI had the highest significant values at zone 1 compared with zone 2 (Table 1, Figure 2). The highest GSI values were observed in zone 1 and the lowest in zone 4. The Condition Factor (CF) had an opposite tendency in relation to GSI, with a non-significant trend to show the highest values in zone 4 .

\section{Discussion}

Increased EROD activity has been reported for fishes exposed to a wide range of pollutants, such as HPAs, BPCs, and TCDDs (Van Der Weiden et al., 1992; Gadagbui et al., 1996; Pacheco and Santos, 1998). Inductions of liver EROD activities have been detected in both, the microsomes (Bainy et al., 1999) and in the S9 fraction (Parente et al., 2004) that worked with tilapia Oreochromis niloticus from different polluted areas. However, information's on eventual differences in EROD activities in fishes exposed to pollutants along the longitudinal gradient river-reservoir are scarce. The findings of the present study detected the lowest EROD activity in a zone where most of the pollutants probably are incorporated in the sediment by decantation due to decreased water flow. In this studied zone, fish species are like to have low influence from xenobiotic exposure. Furthermore, decreased flow could enhance interaction between organic pollutants and heavy metals, resulting in complex forms that sink to sediment and are not incorporated in the biological cycles. In such conditions, the presence of xenobiotics may not induce elevated CYP1A levels (Široká et al., 2005; Bakhtyar and Gagnon, 2011). Previous work in the middle reaches of the Paraíba do Sul River showed critical concentrations of some elements $(\mathrm{Pb}, \mathrm{Cu}, \mathrm{Cr}$ and $\mathrm{Zn})$ in suspended particulate matter (Massena et al., 2007).
The highest EROD activity in zone 4 (river downstream the reservoir) suggests that the Paraíba do Sul River waters can have high levels of xenobiotics compared with the reservoir. It could be linked to structural and operational of the reservoir power plant procedures. For instance, leak of askarel, and oil from PCB derived, formerly employed as an insulator fluid in most voltage converters could be introduced in this part of the river. Additionally, large amount of visceral fat were observed in fishes from zone 4 (C. N. Morado, personal observation) and pollutants could be more easily absorbed by fat tissues as have been observed by Aluru et al. (2004) for the anadromous Arctic charr.

Micronuclei test in fishes erythrocytes response positively to large mutagenics and carcinogenics substances, like as aflatoxinas, benzidinas, heavy metals and polycyclic aromatic hydrocarbons (PAHs) (Al-Sabti and Metcalfe, 1995; Pacheco and Santos, 2002; Srivastava and Singh, 2015). Furnus et al. (2014) found that Steindachnerina brevipinna in the Paraná River had a high frequency of MN that was associated to environmental alterations. Moreover, Linde-Arias et al. (2008a) found that frequencies of MN in Oreochromis niloticus were lower at the reference site than at the others. Zone 1 is likely to be strongly affected by pollutants from Paraiba do Sul River, and this trend was detected by micronuclei.

In most studies high HSI values have been associated to disturbed zones (Karels et al., 1998; Billiard and Khan, 2003), although in a few cases (e.g., Ma et al., 2005; Sadekarpawar and Parikh, 2013) have observed low HSI values in zones next to effluent discharges from sewage treatment plant, and linked the decreased of HSI to sub-lethal toxicity of the effluent. The lowest HSI in zone 2 can be linked to a more pollution retention in this zone associated to decreased flow and synergic effect causing liver intoxication, reflecting in lower HSI in this site.

Alterations in the steroids hormones concentrations in fishes exposed to industrial pollutants were directly connected with the interruption of the reproductive function (McMaster et al., 1991; Munkittrick et al., 1992). Choudhury et al. (1993) observes a decreased in the GSI values in Mystus vittatus after exposure to organophosphate. Sakamoto et al. (2003) studing the cytochrome P450 induction and status of the alteration gonadal in Cyprinus carpio associating with a discharge of the effluents contaminated by dioxins at Hikiji River, Japan, observed lowest GSI values for fishes of the contaminated zone compared to the reference zone. Additionally, Sepúlveda et al. (2004) assessing effects of paper mill effluents (BKME) in reproductive parameters of Micropterus salmoides floridanus observed an inverse relation between GSI and EROD activity. These patterns were also observed in this work since zone 4 had both highest EROD activity and lowest GSI, thus corroborating the hypothesis that the presence of xenobiotics in this zone is likely to occur.

According Tyler and Dunn (1976), CF varies directly with nutrients availability. Sabinson et al. (2014) found the high values of CF and GSI in P. maculatus during the summer and associate this pattern with the reproductive 
period that occur in the rainy season, when a greater gain in weight is expected during the months before the spawning, and that after it occurs the fish loses fat and weight as a consequence of metabolic effort. The CF may also vary in either direction outside the normal range in response to chemical exposure. High CF for Astyanax paranae was associated with well oxygenated and oligotrophic environments, typical of conserved areas or near the natural state in tributary streams of the Monjolinho River, in São Carlos, SE (Barrilli et al., 2015). Moreover, Linde-Arias et al. (2008b) using multibiomarker approach in the fish Geophagus brasiliensis to assess the impact of pollution in the Paraiba do Sul River, found that the reference area had significant higher $\mathrm{CF}$ related to the other sites. On the other hand, high CF has been found in white sucker (Catostomus commersoni) and redbreast sunfish (Lepomis auritus) at sites polluted with pulp mill effluents (McMaster et al., 1991; Adams et al., 1992). Our results are in accordance with these last findings, and in consonance with most of examined tools, indicating the zone 4 as the most disturbed (higher EROD and CF, low GSI), and suggesting that fish in this area are likely to be more exposed to pollutants. Thus, the use of biomarkers e bioindicators in the case of Funil reservoir rejected the hypothesis that reservoirs acts as filters to pollution caused by the inflowing river.

The use of different tools to assess effects of pollutants in aquatic systems by using fishes have been done and the explanations is hardly straightforward (Stegeman, 1992; Bainy, 1993; Franco-Bernardes et al., 2015). Similarly to Linde-Arias et al. (2008b) that used different biomarkers in fish species to assess pollution in the Paraíba do Sul River, our findings revealed different effects in fish from different areas with varying degrees of pollution. Increased concerned in this subject have be raised to untangle relationship between pollution, liver activities and reproductive functions. We should take in account that the CYP1A biologic function encompasses not only the metabolism of xenobiotics agents, but also the synthesis and degradation of endogenous compounds, such as steroids and derived compounds (Sakamoto et al., 2003; Karimzadeh and Zahmatkesh, 2013). Each biomarker and bioindicator has both advantages and disadvantages, but the use of several tools can help to overcome misleading interpretation. These results are novel information on this subject for a native fish species and could be useful for future comparisons with data of fishes belonging to other environments.

\section{Acknowledgements}

We thank students from Laboratory of Fish Ecology, University Federal Rural of Rio de Janeiro for helping in fieldwork. This work was supported by the FAPERJ - Agency for Supporting Research of the Rio de Janeiro State through the grant Cientista do Nosso Estado to FGA (Proc. E-26/201.248/2014).

\section{References}

ADAMS, S.M., CRUMBY, W.D., GREELEY JUNIOR, M.S., SHUGART, L.R. and SAYLOR, C.F., 1992. Responses of fish populations and communities to pulp mill effluents: a holistic assessment. Ecotoxicology and Environmental Safety, vol. 24, no. 3, pp. 347-360. PMid:1282880. http://dx.doi.org/10.1016/01476513(92)90011-Q

AL-SABTI, K. and METCALFE, C.D., 1995. Fish micronuclei for assessing genotoxicity in water. Mutation Research, vol. 343, no. 2-3, pp. 121-135. PMid:7791806. http://dx.doi.org/10.1016/01651218(95)90078-0.

ALURU, N., JORGENSEN, E.H., MAULE, A.G. and VIJAYAN, M.M., 2004. PCB disruption of the hypothalamus-pituitary-interrenal axis involves brain glucocorticoid receptor downregulation in anadromous Arctic charr. American Journal of Physiology. Regulatory, Integrative and Comparative Physiology, vol. 287, no. 4, pp. R787-R793. PMid:15205182. http://dx.doi.org/10.1152/ ajpregu.00091.2004.

ARCIFFA, M.S., FROELICH, O. and NORTHCOTE, T.G., 1988. Distribution and feeding ecology of fishes in a tropical Brazilian reservoir. Memoria de la Fundación La Salle de Ciencias Naturales, vol. 48, pp. 301-326.

BAINY, A.C.D., 1993. How to evaluate the safety chemical substances in aquatic environments. Ciencia e Cultura, vol. 45, pp. 10-11.

BAINY, A.C.D., WOODIN, B.R. and STEGEMAN, J.J., 1999. Elevated levels of multiple cytochrom P450 forms in tilapia from Billings reservoir-São Paulo, Brazil. Aquatic Toxicology, vol. 44, no. 4, pp. 289-305. http://dx.doi.org/10.1016/S0166445X(98)00084-8.

BAKHTYAR, S. and GAGNON, M.M., 2011. Comparison of biomarker responses following one dose of benzo-a-pyrene administered to three native Australian fish species. Journal of the Royal Society of Western Australia, vol. 94, pp. 465-472.

BARRILLI, G.H.C., ROCHA, O., NEGREIROS, N.F. and VERANI, J.R., 2015. Influence of environmental quality of the tributaries of the Monjolinho River on the relative condition factor (Kn) of the local ichthyofauna. Biota Neotropica, vol. 15, no. 1, pp. e20140107. http://dx.doi.org/10.1590/1676-06032015010714.

BILLIARD, S.M. and KHAN, R.A., 2003. Chronic stress in cunner, Tautogolabrus adspersus, exposed to municipal and industrial effluents. Ecotoxicology and Environmental Safety, vol. 55, no. 1, pp. 9-18. PMid:12706388. http://dx.doi.org/10.1016/ S0147-6513(02)00090-8.

BRADFORD, M.M., 1976. A rapid and sensitive method for the quantification of microgram quantities of protein utilizing the principle of protein dye binding. Analytical Biochemistry, vol. 72, no. 1-2, pp. 248-254. PMid:942051. http://dx.doi. org/10.1016/0003-2697(76)90527-3.

BRANCO, C.W.C., ROCHA, M.I.A., PINTO, G.F.S., GÔMARA, G.A. and FILIPPO, R., 2002. Limnological features of Funil Reservoir (R.J., Brazil) and indicator properties of rotifers and cladocerans of the zooplankton community. Lakes and Reservoirs: Research and Management, vol. 7, no. 2, pp. 87-92. http://dx.doi. org/10.1046/j.1440-169X.2002.00177.x.

BURKE, M.D., THOMPSON, S., ELCOMBE, C.R., HALPERT, J., HAAPARANTA, T. and MAYER, R.T., 1985. Ethoxy-, penthoxyand benzyloxy-phenoxazones and homologues: a series of substrates to distinguish between different induced cytochromes 
P450. Biochemical Pharmacology, vol. 34, no. 18, pp. 3337-3345. PMid:3929792. http://dx.doi.org/10.1016/0006-2952(85)90355-7.

ÇAVAŞ, T. and ERGENE-GOZUKARA, S., 2005a. Induction of micronuclei and nuclear abnormalities in Oreochromis niloticus following exposure to petroleum refinery and chromium processing plant effluents. Aquatic Toxicology, vol. 74, no. 3, pp. 264-271. PMid:16023743. https://doi.org/10.1016/j.aquatox.2005.06.001.

ÇAVAŞ, T. and ERGENE-GOZUKARA, S., 2005b. Micronucleus test in fish cells: a bioassay for in situ monitoring of genotoxic pollution in marine environment. Environmental and Molecular Mutagenesis, vol. 46, no. 1, pp. 64-70. _PMid:15880416. http:// dx.doi.org/10.1002/em.20130.

CHOUDHURY, C., RAY, A., BHATTACHARYA, S. and BHATTACHARYA, S., 1993. Non-lethal concentrations of pesticide impair ovarian function in the freshwater perch, Anabas testudineus. Environmental Biology of Fishes, vol. 36, no. 3, pp. 319-324. http://dx.doi.org/10.1007/BF00001728.

CLEMENTS, W.H., 2000. Integrating effects of contaminants across levels of biological organization. Journal of Aquatic Ecosystem Stress and Recovery, vol. 7, no. 2, pp. 113-116. http:// dx.doi.org/10.1023/A:1009927612391.

COSTA, I.A.S., AZEVEDO, S.M.F.O., SENNA, P.A.C., BERNARDO, R.R., COSTA, S.M. and CHELLAPPA, N.T., 2006. Occurrence of toxin-producing cyanobacteria blooms in a Brazilian semiarid reservoir. Brazilian Journal of Biology $=$ Revista Brasileira de Biologia, vol. 66, no. 1B, pp. 211-219. PMid:16710515. http:// dx.doi.org/10.1590/S1519-69842006000200005.

DE VLAMING, V.L., GROSSMAN, G. and CHAPMAN, F., 1981. On the use of gonadosomatic index. Comparative Biochemistry and Physiology, vol. 73A, pp. 31-39.

FACEY, D.E., LECLERC, C., DUNBAR, D., ARRUDA, D., PYZOCHA, L. and BLAZER, V., 1999. Physiological indicators of stress among fishes from contaminated areas of Lake Champlain. In: T.O. MANLEY and P.L. MANLEY. Lake Champlain in transition: from research toward restoration water science and application. Washington: American Geophysical Union, p. 349-359.

FRANCO-BERNARDES, M.F., MASCHIO, L.R., AZEREDOOLIVEIRA, M.T.V. and ALMEIDA, E.A., 2015. The use of biomarkers to study the effects of the mixture of diuron and hexazinone on small and large O. niloticus. Ecotoxicology and Environmental Contamination, vol. 10, no. 1, pp. 83-92. http:// dx.doi.org/10.5132/eec.2015.01.12.

FURNUS, G.N.A., CAFFETTI, J.D., GARCÍA, E.M., BENÍTEZ, M.F., PASTORI, M.C. and FENOCCHIO, A.S., 2014. Baseline micronuclei and nuclear abnormalities frequencies in native fishes from the Paraná River (Argentina). Brazilian Journal of Biology = Revista Brasileira de Biologia, vol. 74, no. 1, pp. 217-221. PMid:25055105. http://dx.doi.org/10.1590/1519-6984.13712.

GADAGBUI, B.K.M., ADDY, M. and GOKSOYR, A., 1996. Species characteristics of hepatic biotransformation enzymes in two tropical freshwater teleosts, tilapia (Oreochromis niloticus) and mudfish (Clarias anguillaris). Comparative Biochemistry and Physiology, vol. 114, pp. 201-211.

GOEDE, R.W. and BARTON, B.A.,1990. Organismic indices and an autopsy-based assessment as indicators of health and condition of fish. In: S.M. ADAMS. Biological indicators of stress in fish. Bethesda: American Fisheries Society, pp. 93-108.

HANDY, R.D., GALLOWAY, T.S. and DEPLEDGE, M.H., 2003. A proposal for the use of biomarkers for the assessment of chronic pollution and in regulatory toxicology. Ecotoxicology, vol. 12, no. 1-4, pp. 331-343. PMid:12739879. http://dx.doi. org/10.1023/A:1022527432252.

HUTZINGER, O. and VEERKAMP, W., 1981. Xenobiotic chemicals with pollution potential. In: T. LEISINGER, A. M. COOK, R. HÜTTER and J. NUESCH. Microbial degradation of xenobiotics and recalcitrant compounds. New York: Academic Press, pp. 3-45.

JUNG, D.K., KLAUS, T. and FENT, K., 2001. Cytocrome $\mathrm{P} 450$ induction nitrated polycyclic aromatic hydrocarbons, azaarenes, and binary mixtures in fish hepatoma cell line PLHC-1. Environmental Toxicology and Chemistry, vol. 20, no. 1, pp. 149159. PMid:11351403. http://dx.doi.org/10.1002/etc.5620200117.

KARELS, A.E., SOIMASUO, M., LAPPIVAARA, J., LEPPANEN, H., AALTONEN, T., MELLANEN, P. and OIKARI, A.O.J., 1998. Effects of EFC-bleached kraft mill effluent on reproductive steroids and liver MFO activity in populations of pearch and roach. Ecotoxicology, vol. 7, no. 3, pp. 123-132. http://dx.doi. org/10.1023/A:1014376825777.

KARIMZADEH, K. and ZAHMATKESH, A., 2013. Biomarker responses in persian sturgeon (Acipenser persicus) exposed to benzo-a-pyrene and beta-naphthoflavone. Archives of Biological Sciences, vol. 65, no. 4, pp. 1397-1403. http://dx.doi.org/10.2298/ ABS1304397K.

KLAPPER, H., 1998. Water quality in reservoirs of Rio de Janeiro, Minas Gerais and São Paulo. International Review of Hydrobiology, vol. 83, pp. 93-102.

KLAPPER, H., 2003. Technologies for lake restoration. Journal of Limnology, vol. 62, no. 1s, suppl. 1, pp. 73-90. http://dx.doi. org/10.4081/jlimnol.2003.s1.73.

LE CREN, E.D., 1951. The length-weight relationship and seasonal cycle in gonad weight and condition in the perch (Perca fluviatilis). Journal of Animal Ecology, vol. 20, no. 2, pp. 201-219. http:// dx.doi.org/10.2307/1540.

LINDE-ARIAS, A.R., INACIO, A.F., ALBUQUERQUE, C., FREIRE, M.M. and MOREIRA, J.C., 2008a. Biomarkers in an invasive fish species, Oreochromis niloticus, to assess the effects of pollution in a highly degraded Brazilian River. The Science of the Total Environment, vol. 399, no. 1-3, pp. 186-192. PMid:18468656. http://dx.doi.org/10.1016/j.scitotenv.2008.03.028.

LINDE-ARIAS, A.R., INACIO, A.F., NOVO, L.A., ALBUQUERQUE, C. and MOREIRA, J.C., 2008b. Multibiomarker approach in fish to assess the impact of pollution in a large Brazilian river, Paraiba do Sul. Environmental Pollution, vol. 156, no. 3, pp. 974-979. PMid:18524439. http://dx.doi.org/10.1016/j.envpol.2008.05.006.

LOHANI, B.N. and SANTOS, N.L., 1994. Environmental impacts of integrated fisheries development in the Bicol River basin, the Philippines. International Journal of Water Resources Development, vol. 2, no. 1, pp. 61-74. http://dx.doi. org/10.1080/07900628408722308.

LOLIS, A.A. and ANDRIAN, I.F., 1996. Alimentação de Pimelodus maculatus Lacépède, 1803 (Siluriformes, Pimelodidae), na planície de inundação do alto do rio Paraná, Brasil. Boletim do Instituto de Pesca, vol. 23, pp. 187-202.

LU, G.H., WANG, C. and ZHU, Z., 2009. The dose-response relationships for erod and gst induced by polyaromatic hydrocarbons in Carassius auratus. Bulletin of Environmental Contamination and Toxicology, vol. 82, no. 2, pp. 194-199. PMid:19034369. http://dx.doi.org/10.1007/s00128-008-9622-3. 
MA, T., WAN, X., HUANG, Q., WANG, Z. and LIU, J., 2005. Biomarker responses and reproductive toxicity of effluent from a Chinese large sewage treatment plant in Japanese medaka (Oryzias latipes). Chemosphere, vol. 59, no. 2, pp. 281-288. PMid:15722100. http://dx.doi.org/10.1016/j.chemosphere.2004.11.033.

MASSENA, E.P., PEREIRA, M.S., TORRES, J.P.M. and MALM, O., 2007. Evaluation of the potability of the drinking water stemming from the Guandu Paraíba do Sul Riverine System, Rio de Janeiro, Brazil: a first screen regarding metals and persistent organic pollutants. Oecologia Brasiliensis, vol. 11, pp. 213-218. http://dx.doi.org/10.4257/oeco.2007.1102.05.

MC CARTHY, J.F. and SCHUGART, L.R., 1990. Biological markers of environmental contamination. Chelsea: Lewis Publishers. $457 \mathrm{p}$.

MC MASTER, M.E., VAN DER KRAAK, G.J., PORTT, C.B., MUNKITTRICK, K.R., SIBLEY, P.K., SMITH, I.R. and DIXON, D.G., 1991. Changes in hepatic mixed-function oxygenase (MFO) activity, plasma steroid levels and age at maturity of a white sucker (Catostomus commersoni) population exposed to bleached kraft pulp mill effluent. Aquatic Toxicology, vol. 21, no. 3-4, pp. 199218. http://dx.doi.org/10.1016/0166-445X(91)90073-I.

MOORE, M.N. and SIMPSON, M.G., 1992. Molecular and cellular pathology in environmente impact assessment. Aquatic Toxicology, vol. 22 , no. 4 , pp. 313-322. http://dx.doi.org/10.1016/0166445X(92)90047-Q.

MUNKITTRICK, K.R., VAN DER KRAAK, G.J., MCMASTER, M.E. and PORTT, C.B., 1992. Response of hepatic MFO activity and plasma sex steroids to secondary treatment of bleached kraft pulp mill effluent and mill shutdown. Environmental Toxicology and Chemistry, vol. 11, no. 10, pp. 1427-1439. http://dx.doi. org/10.1897/1552-8618(1992)11[1427:ROHMAA]2.0.CO;2.

PACHECO, M. and SANTOS, M.A., 1998. Induction of liver EROD and erythrocytic nuclear abnormalities by cyclophosphamide and PAHs in Anguilla anguilla L. Ecotoxicology and Environmental Safety, vol. 40, no. 1-2, pp. 71-76. PMid:9626538. http://dx.doi. org/10.1006/eesa.1998.1644.

PACHECO, M. and SANTOS, M.A., 2002. Biotransformation, genotoxic, and histopathological effects of environmental contaminants in European eel (Anguilla Anguilla L.). Ecotoxicology and Environmental Safety, vol. 53, no. 3, pp. 331-347. PMid:12485576. http://dx.doi.org/10.1016/S0147-6513(02)00017-9.

PARENTE, T.E., DE-OLIVEIRA, A.C., SILVA, I.B., ARAUJO, F.G. and PAUMGARTTEN, F.J., 2004. Induced alkoxyresorufinO-dealkylases in tilapias (Oreochromis niloticus) from Guandu River, Rio de Janeiro, Brazil. Chemosphere, vol. 54, no. 11, pp. 1613-1618. PMid:14675840. http://dx.doi.org/10.1016/j. chemosphere.2003.09.027.

PARENTE, T.E., REBELO, M.F., SILVA, M.L., WOODIN, B.R., GOLDSTONE, J.V. and BISCH, P.M. PAUMGARTTEN, F.J. and STEGEMAN, J.J., 2011. Structural features of cytochrome P450 1A associated with the absence of Erod activity in liver of the loricariid catfish Pterygoplichthys sp. Gene, vol. 489, no. 2, pp. 111-118. PMid:21840383. http://dx.doi.org/10.1016/j. gene.2011.07.023.

PARENTE, T.E., SANTOS, L.M.F., OLIVEIRA, A.C.A.X., TORRES, J.P.M., ARAUJO, F.G., DELGADO, I.F. and PAUMGARTTEN, F.J.R., 2015. The concentrations of heavy metals and the incidence of micronucleated erythrocytes and liver EROD activity in two edible fish from the Paraíba do Sul River basin in Brazil. Vigilancia Sanitaria em Debate, vol. 3, no. 1, pp. 88-92.
RAMSDORF, W.A., VICARI, T., ALMEIDA, M.I.M., ARTONI, R.F. and CESTARI, M.M., 2012. Handling of Astyanax sp. for biomonitoring in Cangüiri Farm within a fountainhead (Iraí River Environment Preservation Area) through the use of genetic biomarkers, 2012. Environmental Monitoring and Assessment, vol. 184, no. 10, pp. 5841-5849. PMid:22821320. http://dx.doi. org/10.1007/s10661-012-2752-4

REYNOLDS, W.J., FEIST, S.W., JONES, G.J., LYONS, B.P., SHEAHAN, D.A. and STENTIFORD, G.D., 2003. Comparison of biomarker and pathological responses in flounder (Platichthys flesus L.) induced by ingested polycyclic aromatic hydrocarbon (PAH) contamination. Chemosphere, vol. 52, no. 7, pp. 1135-1145. PMid:12820994. http://dx.doi.org/10.1016/S0045-6535(03)00332-1.

ROCHA, M.I.A., BRANCO, C.W.C., SAMPAIO, G.F., GÔMARA, G.A. and FILIPPO, R., 2002. Spatial and temporal variation of limnological features, Microcystis aeruginosa and zooplankton in a eutrophic reservoir (Funil Reservoir, Rio de Janeiro). Acta Limnologica Brasiliensia, vol. 14, pp. 73-86.

SABINSON, L.M., RODRIGUES FILHO, J.L., PERET, A.C. and VERANI, J.R., 2014. Growth and reproduction aspects of Pimelodus maculatus Lacépède, 1803 (Siluriformes, Pimelodidae) of the Cachoeira Dourada reservoir, state of Goiás and Minas Gerais, Brazil. Brazilian Journal of Biology $=$ Revista Brasileira de Biologia, vol. 74, no. 2, pp. 450-459. PMid:25166330. http:// dx.doi.org/10.1590/1519-6984.09012.

SADEKARPAWAR, S. and PARIKH, P., 2013. Gonadosomatic and Hepatosomatic indices of freshwater fish world. Journal of Zoology, vol. 8, no. 1, pp. 110-118.

SAKAMOTO, K.Q., NAKAI, K., AOTO, T., YOKOYAMA, A., USHIKOSHI, R., HIROSE, H., ISHIZUKA, M., KAZUSAKA, A. and FUJITA, S., 2003. Cytochrome P450 induction and gonadal status alteration in common carp (Cyprinus carpio) associated with the discharge of dioxin contaminated effluent to the Hikiji River, Kanagawa Prefecture, Japan. Chemosphere, vol. 51, no. 6, pp. 491-500. PMid:12615101. http://dx.doi.org/10.1016/ S0045-6535(03)00005-5.

SCHIRMER, M., REINSTORF, F., LESCHIK, S., MUSOLFF, A., KRIEG, R., STRAUCH, G., MOLSON, J.W., MARTIENSSEN, M. and SCHIRMER, K., 2011. Mass fluxes of xenobiotics below cities: challenges in urban hydrogeology. Environmental Earth Sciences, vol. 64, no. 3, pp. 607-617. http://dx.doi.org/10.1007/ s12665-010-0880-0.

SCHULZ, U.H. and MARTINS-JUNIOR, H., 2001. Astyanax fasciatus as bioindicator of water pollution of rio dos Sinos, RS, Brazil. Brazilian Journal of Biology $=$ Revista Brasileira de Biologia, vol. 61, no. 4, pp. 615-622. PMid:12071317. http:// dx.doi.org/10.1590/S1519-69842001000400010.

SEPÚLVEDA, M.S., GALLAGHER, E.P., WIESER, C.M. and GROSS, T.S., 2004. Reproductive and biochemical biomarkers in largemouth bass sampled downstream of a pulp and paper mill in Florida. Ecotoxicology and Environmental Safety, vol. 57, no. 3, pp. 431-440. PMid:15041266. http://dx.doi.org/10.1016/j. ecoenv.2003.08.020.

SHOTBOLT, L.A., THOMAS, A.D. and HUTCHINSON, S.M., 2005. The use of reservoir sediments as environmental archives of catchment inputs and atmospheric pollution. Progress in Physical Geography, vol. 29, no. 3, pp. 337-361. http://dx.doi. org/10.1191/0309133305pp452ra.

ŠIROKÁ, Z., KRIJT, J., RANDÁK, T., SVOBODOVÁ, Z., PEŠKOVÁ, G., FUKSA, J., HAJŠLOVÁ, J., JARKOVSKÝ, J. 
and JÁNSKÁ, M., 2005. Organic pollutant of the River Elbe as assessed by biochemical markers. Acta Veterinaria Brno, vol. 74, no. 2, pp. 293-303. http://dx.doi.org/10.2754/avb200574020293.

SOLÉ, M., ANTÓ, M., BAENA, M., CARRASSON, M., CARTES, J.E. and MAYNOU, F., 2010. Hepatic biomarkers of xenobiotic metabolism in eighteen marine fish from NW Mediterranean shelf and slope waters in relation to some of their biological and ecological variables. Marine Environmental Research, vol. 70, no. 2, pp. 181-188. PMid:20494437. http://dx.doi.org/10.1016/j. marenvres.2010.04.008.

SOLÉ, M., RODRÍGUEZ, S., PAPIOL V., MAYNOU, F. and CARTES, J.E., 2009. Xenobiotic metabolism markers in marine fish with different trophic strategies and their relationship to ecological variables. Comparative Biochemistry and Physiology, vol. 149, no. 1, pp. 83-89. PMid:18708160. http://dx.doi.org/10.1016/j. cbpc.2008.07.008.

SRIVASTAVA, P. and SINGH, A., 2015. Evidence of micronuclei in fish blood as a biomarker of genotoxicity due to surface run off agricultural fungicide (Propiconazole). Journal of Toxicology and Enviromnental Health Sciences, vol. 7, no. 1, pp. 4-8. http:// dx.doi.org/10.5897/JTEHS2015.0325.

STEGEMAN, J.J. and LECH, J.J., 1991. Cytocrome P-450 monooxigenase systems in aquatic species: carcinogen metabolism and biomarkers for carcinogen and pollutant exposure. Environmental Health Perspectives, vol. 90, pp. 101-109. PMid:2050047. http:// dx.doi.org/10.2307/3430851.

STEGEMAN, J.J., 1992. Nomenclature for hydrocarboninducible cytochrome P450 in fish. Marine Environmental Research, vol. 34, no. 1-4, pp. 133-138. http://dx.doi.org/10.1016/01411136(92)90097-6.

STEGEMAN, J.J., WOODIN, B.R., SINGH, H., OLEKSIAK, M.F. and CELANDER, M., 1997. Cytochromes P450 (CYP) in tropical fishes: catalytic activities, expression of multiple CYP proteins and high levels of microsomal P450 in liver of fishes from Bermuda. Comparative Biochemistry and Physiology, vol. 116, no. 1, pp. 61-75. PMid:9080675.
SUNDBORG, A., 1992. Lake and reservoir sedimentation. Prediction and interpretation. Geografiska Annaler, vol. 74A, no. 2-3, pp. 93-100. http://dx.doi.org/10.2307/521287.

SUTTON, S.G., BULT, T.P. and HAEDRICH, R.L., 2000. Relationships among fat weight, body weight, water weight, and condition factors in wild Atlantic salmon par. Transactions of the American Fisheries Society, vol. 129, no. 2, pp. 527-538. http://dx.doi.org/10.1577/1548-8659(2000)129<0527:RAFW $\mathrm{BW}>2.0 . \mathrm{CO} ; 2$

TONIOLO, H. and SCHULTZ, J., 2005. Experiments on sediment trap efficiency in reservoirs. Lakes and Reservoirs: Research and Management, vol. 10, no. 1, pp. 13-24. http://dx.doi. org/10.1111/j.1440-1770.2005.00256.x.

TYLER, A.V. and DUNN, R.S., 1976. Ration, growth, and measures of somatic and organ condition in relation to meal frequency in winter flounder, Pseudopleuronectes americanus, with hypotheses regarding population homeostasis. Journal of the Fisheries Research Board of Canada, vol. 33, no. 1, pp. 63-75. http://dx.doi.org/10.1139/f76-008.

VAN DER OOST, R., BEYER, J. and VERMEULEN, N.P.E., 2003. Fish bioaccumulation and biomarkers in environmental risk assessment: a review. Environmental Toxicology and Pharmacology, vol. 13, no. 2, pp. 57-149. PMid:21782649. http:// dx.doi.org/10.1016/S1382-6689(02)00126-6.

VAN DER WEIDEN, M.E.J., VAN DER KOLK, J., BLEUMINK, R., SEINEN, W. and VAN DER BERG, M., 1992. Concurrence of P450 1A1 induction and toxic effects alter administration of a low dose of 2, 3, 7, 8-tetrachlorodibenzo- $p$-dioxin (TCDD) in the rainbow trout (Oncorhynchus mykiss). Aquatic Toxicology, vol. 24, no. 1-2, pp. 123-142. http://dx.doi.org/10.1016/0166$445 \mathrm{X}(92) 90020-\mathrm{N}$.

WHYTE, J.J., JUNG, R.E., SCHMITT, C.J. and TILLITT, D.E., 2000. Ethoxyresorufin-O-deethylase (EROD) activity in fish as a biomarker of chemical exposure. Critical Reviews in Toxicology, vol. 30, no. 4, pp. 347-570. PMid:10955715. http:// dx.doi.org/10.1080/10408440091159239. 